
ПОРІВНЯЛЬНИЙ АНАЛІЗ СТРАТЕГІЧНИХ ПІДХОДІВ ЩОДО АЛОКАЦІЇ
АКТИВІВ У ПАСИВНОМУ УПРАВЛІННІ ІНВЕСТИЦІЙНИМ ПОРТФЕЛЕМ

\title{
COMPARATIVE ANALYSIS OF STRATEGIC APPROACHES TO ASSET ALLOCATION IN PASSIVE INVESTMENT PORTFOLIO MANAGEMENT
}

\begin{abstract}
У статті окреслено різницю між активною та пасивною стратегіями управління інвестиційним порторелем, останню визначено як більш доступну для широкого кола інвесторів. Розглянуто динаміку чотирьох інвестиційних порторелів із різним рівнем диверсифрікації, сорормованих за чотирма стратегічними підходами пасивного управління з інструментів, що репрезентують певний клас активів, за останні двадиять років та проаналізовано показники ефективності зазначених портфелів, такі як баланс наприкінці періоду інвестування, середньорічний приріст капіталу, середньорічна волатильність, коефріцієнт Бета та інші. Розглянуто основні переваги та недоліки кожного з утворених портфелів. Визначено підхід, який за комплексним аналізом показників є найбільш оптимальним та дає змогу сорормувати найбільш ефективний інвестичійний порторель. Досліджено вплив чотирьох рівнів диверсифрікації та п'яти способів ребалансування на показники портфеля.

Ключові слова: інвестиційний портфель, фрінансові інструменти, алокація, диверсифікація, ребалансування.
\end{abstract}

В статье выделены различия между активной и пассивной стратегиями управления инвестиционным портфелем, последняя определена как более доступная для широкого круга инвесторов. Рассмотрена динамика четырех инвестиционных порторелей с различным уровнем диверсификации, сорормированных по четырем стратегическим подходам пассивного управления из инструментов, представляющих определенный класс активов, за последние двадцать лет и проанализированы показатели эфрфективности указанных портфелей, такие как баланс в коние периода инвести рования, среднегодовой прирост капитала, среднегодовая волатильность, коэфорициент Бета и другие. Рассмотрены основные преимущества и недостатки каждого из сорормированных портоелей. Определен подход, который по комплексному анализу показателей является оптимальным u позволяет сфрормировать наиболее эфорективный инвестиционный портфель. Исследовано влияние четырех уровней диверсифокации и пяти способов ребалансирования инструментов в портореле на показатели портореля.

Ключевые слова: инвестиционный портфель, финансовые инструменты, аллокация, диверсификация, ребалансирование.

Odesa National Economic University

The article outlines the difference between active and passive investment portfolio management strategies. Passive strategies, although not on average more profitable than active ones, they are also less risky and are suitable for investors with a risk-conservative profile of investment preferences. Passive strategies are also available to a wider range of investors, as they do not require special skills in analyzing and managing the investment portfolio. Analyzed the dynamics of four investment portfolios with different levels of diversification, formed by four strategic approaches of passive management from instruments representing a certain asset class, over the last twenty years and analyzed the performance of these portfolios, such as final balance, CAGR, standard deviation, Beta coefficient, maximal drawdown, Sharpe ratio, gain/loss ratio, minimal investment amount and underwater period. The main advantages and disadvantages of each of the formed are analyzed: Passive stock portfolio reflects the United States stock market. The main advantage of such a portfolio is the lowest minimal required initial balance. The main disadvantage is the extremely high drawdown of -50.89\%, so this portfolio is the least acceptable for risk-averse investors. Moderate investment portfolio showed the highest return among all other simulated portfolios. However, the maximum drawdown may be unacceptable for investors with a risk-conservative preference profile, the minimal required initial balance is higher, and with the need to rebalance, the cost of commissions paid over the period of ownership increases. Conservative investment portfolio is the most acceptable for conservative investors, as its return is even higher than the return on the passive stock portfolio, but it is the least risky, as evidenced by the best volatility, maximum drawdown, Beta and Sharpe ratios. However, this portfolio is less accessible to investors due to the higher minimal required initial balance. Risk-conservative investment portfolio includes gold, which has historically been a protective and anti-inflationary asset. The profitability of the portfolio is second only to the moderate portfolio, and the risk - to the conservative. It has the best rate of return on risk taken, as well as the most rapid correction and the lowest beta ratio. Having the largest number of assets in the warehouse, it also has the highest entry threshold. The approach which according to the complex analysis of indicators is the most optimum and allows to form the most effective investment portfolio is defined. The impact of four levels of diversification and five ways of rebalancing on portfolio performance has been studied.

Key words: investment portfolio, financial instruments, allocation, diversification, rebalancing.

Постановка проблеми. 3 розвитком фрінансових технологій поглиблюється також і фрінансова глобалізація, а разом з нею покращується інвестиційна інфрраструктура. Ці процеси приводять до підвищення доступності ринків капіталу різних країн для більшого кола інвесторів. А оскільки пасивне управління інвестиційним портфелем є доступним інструментом помноження капіталу для будь-якого інвестора, постає необхідність дослідження шляхів оптимізації цієї стратегії, що дасть змогу створювати більш ефективні інвестиційні портфелі.

Аналіз останніх досліджень і публікацій. Дослідженню стратегій управління інвестиційним порторелем присвячені наукові праці вітчизняних учених О. Бібко та В. Гужви. Проблемам оцінки ризику і доходності в управлінні інвестиційним порторелем присвячені праці У. Шарпа, Г. Александера, Дж. Бейлі, Б. Малкіела.

Стратегія пасивного управління інвестиційним порторелем передбачає мінімальну активність інвестора, який лише на початку періоду інвестування визначається зі структурою портореля та залишає його незмінним до кінця періоду інвестування. Проте інвестор має змогу використовувати низку підходів, таких як алокація та ребалансування активів, котрі не порушують засад стратегії 
пасивного управління, проте можуть значно підвищити ефективність портфеля. Доцільність використання вищезазначених підходів потребує більш детального дослідження.

Постановка завдання. Завданням статті $\epsilon$ підвищення ефективності пасивного управління інвестиційним портфелем шляхом аналізу стратегічних підходів щодо алокації активів в інвестиційному порторелі та визначення найбільш оптимального підходу, що дасть змогу покращити кількісні показники портфеля наприкінці періоду інвестування, такі як дохідність інвестицій та максимальна просадка портореля. Ці дослідження розраховані на портфельних менеджерів інвестиційних фрондів, індивідуальних інвесторів та науковців, які займаються дослідженнями у сорері прямих портфельних інвестицій.

Виклад основного матеріалу. Інвестиційний порторель - це цілеспрямовано сфрормована сукупність об'єктів фрінансового та/або реального інвестування, призначена для реалізації попередньо розробленої стратегії, що визначає інвестиційну мету. Складниками інвестиційного портфеля можуть бути будь які активи - від золота і нерухомості до акцій і опціонів. Він належить одному інвестору й управляється як єдине ціле для досягнення визначених цілей [1].

У світовій практиці виділяють дві основні стратегії управління інвестиційним порторелем: активну та пасивну.

Головною метою активного управління інвестиційним порторелем $€$ перевищення дохідності базового індексу. Під час активного управління реалізується можливість отримання доходу за рахунок постійних операцій купівлі-продажу цінних паперів та проектів, тобто за рахунок зміни структури портореля [1]. Кваліфрікований менеджер із портфельного управління, який підтримується спеціалізованою інвестиційною командою, може вибрати такі цінні папери для портореля, які перевищать прибутки у порівнянні з базовим індексом або іншим відповідним показником ефективності портореля. Інвестори сплачують менеджеру портфреля за його досвід, що переходить до вибору цінних паперів, сподіваючись, що його поглиблене дослідження дасть сприятливі результати, які компенсують плату, яка, як правило, перевищує пасивну стратегію.

Натомість інвестиційна фрілософрія пасивного управління портфелем базується на гіпотезі ефективного ринку. Ця теорія постулює, що фрінансові ринки $€$ ефрективними щодо ціноутворення. Всі інвестори мають усю інорормацію, яка їм доступна, без внутрішньої інорормації, яка могла б принести користь певному сегменту ринку. Якщо це так, то для інвестора є мало місця, якщо воно $€$, щоб перевершити дохідність ринку, тим самим визначаючи активне управління інвестиційним порторелем менш ефрективним. Тому пасивне управління порторелем фрокусується на зменшенні витрат, виконуючи стратегію купівлі-утримання, що тягне за собою низький оборот портфеля.

Дискусії щодо ефрективності тієї чи іншої стратегії управління інвестиційним портфелем виникають і донині. Проте, зважаючи на світову практику, обидві стратегії мають право на існування та наділені власними недоліками та перевагами. У світі існують успішні менеджери активної стратегії, які в довгостроковому періоді перевищують дохідність індексів фондових ринків, однак існує ще більше фондів активного управління, які не можуть забезпечити для інвесторів дохідність вищу, ніж індексну дохідність. До того ж активні стратегії управління інвестиційним порторелем $є$ ризик-агресивними, тобто є прийнятними лише для інвесторів із ризикагресивним профрілем інвестиційних вподобань.

Пасивні стратегії, хоча й не $€$ у середньому більш дохідними, ніж активні, водночас $€$ й менш ризиковими та підходять для інвесторів із ризикконсервативним профрілем інвестиційних уподобань. Пасивні стратегії також є доступними для більш широкого кола інвесторів, адже не передбачають особливих навичок в аналізі та управлінні інвестиційним порторелем.

Б. Малкіел зазначав, що правильна інвестиційна стратегія полягає у вкладенні коштів у різні категорії активів і диверсифікації вкладень у кожній із цих категорій [2, с. 92]. При цьому інвестори пасивних стратегій є вільними у виборі стратегічних підходів щодо комбінацій тих чи інших індексних інвестицій та відповідної алокації фрінансових інструментів в інвестиційному портоелі. Отже, проведемо порівняльний аналіз чотирьох стратегічних підходів на основі чотирьох інвестиційних порторелів, наведених у табл. 1, з умовними назвами, які складаються з різних класів активів. Усі зазначені облігації в списку активів є державними облігаціями.

Основне припущення під час фрормування порторелів: інвестор використовує пасивну стратегію управління, тобто, прийнявши рішення про фрормування портфеля на початку періоду інвестування, надалі не змінює складу активів портореля.

Кожен наступний портфель становить вищий рівень диверсифікації, ніж попередній. Фінансові інструменти у портфелі наведені індексними фондами, які репрезентують вибраний клас активів таким чином, інвестору немає необхідності самостійно проводити реплікацію того чи іншого індексу або класу активів, що також $є$ рисою пасивного управління інвестиційним порторелем. Це також зумовлено тим, що кожний окремий інструмент, який входить до того чи іншого класу активів, не $€$ кращим, ніж будь-який інший, та залежить від уподобань конкретного інвестора [7, с. 16], а отже, вибір індексного фронду є найбільш оптимальним 
варіантом. Характеристики фрінансових інструментів, що включені до порторелів, такі як дохідність, зазначені в джерелах 3-6.

Розпочнемо порівняльний аналіз із початкових припущень: нехай інвестор на початку 2000 року вклав у кожний портфель $\$ 10$ 000. Також на початку кожного року інвестор виконує ребалансування часток фрінансових інструментів у портфрелях, тобто продає частку активів, що зросла, та придбає частку активів, що знизилася в ціні, нормалізуючи алокації до початкового стану.

Розглянемо динаміку вартості порторелів у грошовому виразі починаючи 301.01 .2000 і до 01.06.2020, яка відображена на рис. 1.

Як можна побачити з рис. 1, найбільшу вартість наприкінці періоду інвестування має помірний порторель, який складається з ринку акцій США та довгострокових облігацій. При цьому найменша дохідність виявлена у портореля, що є повністю представлений ринком акцій США. Тобто вже можна зробити висновок, що звичайна диверсифрікація портфеля акцій з ризик-консервативними фрінансовими інструментами підвищує дохідність, все ще не виходячи за межі пасивного управління інвестиційним порторелем. Для подальшого аналізу розглянемо характеристику кожного 3 портфелів, що відображена в таблиці.

Розглянемо переваги та недоліки кожного 3 порторелів:

1. Пасивний портфель акцій (ПАС). Фактично цей порторель відображає ринок акцій Сполучених Штатів загалом. Головною перевагою такого

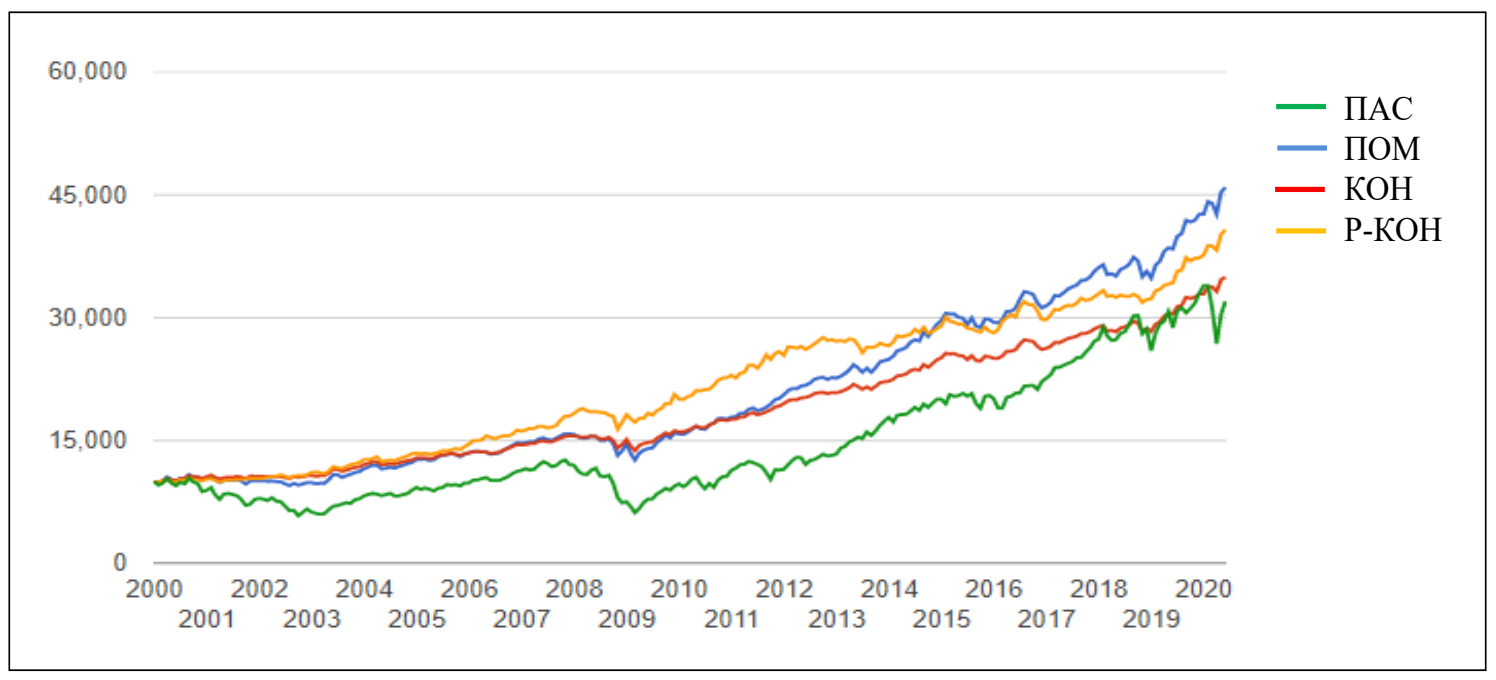

Рис. 1. Динаміка вартості портфелів, дол. США

Джерело: складено автором на основі [8]

Таблиця 1

Характеристика складу портфелів

\begin{tabular}{|c|c|c|}
\hline Назва портфеля: & \multicolumn{2}{|c|}{ 1. Пасивний портфель акцій (ПАС) } \\
\hline Клас активів & $\begin{array}{c}\text { Фінансовий інструмент, } \\
\text { що репрезентує вибраний клас активів }\end{array}$ & $\begin{array}{c}\text { Алокація } \\
\text { інструменту } \\
\text { в портфелі }\end{array}$ \\
\hline Ринок акцій США & Vanguard Total Stock Mkt Idx Inv (VTSMX)[3] & $100 \%$ \\
\hline \multicolumn{3}{|c|}{ 2. Помірний інвестиційний порторель (ПОМ) } \\
\hline Ринок акцій США & Vanguard Total Stock Mkt Idx Inv (VTSMX) & $50 \%$ \\
\hline Довгострокові облігації США & Vanguard Long-Term Treasury Inv (VUSTX)[4] & $50 \%$ \\
\hline \multicolumn{3}{|c|}{ 3. Консервативний інвестиційний портфель (КОН) } \\
\hline Ринок акцій США & Vanguard Total Stock Mkt Idx Inv (VTSMX) & $33,33 \%$ \\
\hline Довгострокові облігації США & Vanguard Long-Term Treasury Inv (VUSTX) & $33,33 \%$ \\
\hline Короткострокові облігації США & Vanguard Short-Term Treasury Inv (VFISX) [5] & $33,33 \%$ \\
\hline \multicolumn{3}{|c|}{ 4. Ризик-консервативний інвестиційний портфель (Р-КОН) } \\
\hline Ринок акцій США & Vanguard Total Stock Mkt Idx Inv (VTSMX) & $25 \%$ \\
\hline Довгострокові облігації США & Vanguard Long-Term Treasury Inv (VUSTX) & $25 \%$ \\
\hline Короткострокові облігації США & Vanguard Short-Term Treasury Inv (VFISX) & $25 \%$ \\
\hline Золото & SPDR Gold Shares (GLD) [6] & $25 \%$ \\
\hline
\end{tabular}

Джерело: складено автором 
Основні показники портфелів наприкінці періоду інвестування

\begin{tabular}{|l|c|c|c|c|}
\hline \multicolumn{1}{|c|}{ Показник портфелю } & ПАС & ПОМ & KOH & P-KOH \\
\hline Баланс наприкінці періоду інвестування & $32017 \$$ & $45906 \$$ & $34962 \$$ & $40735 \$$ \\
\hline Середньорічний приріст капіталу & $5,87 \%$ & $7,75 \%$ & $6,32 \%$ & $7,12 \%$ \\
\hline Середньорічна волатильність & $15,51 \%$ & $7,76 \%$ & $5,25 \%$ & $6,38 \%$ \\
\hline Коефіцієнт Бета & 1,00 & 0,36 & 0,23 & 0,18 \\
\hline Максимальна просадка & $-50,89 \%$ & $-20,39 \%$ & $-11,74 \%$ & $-13,38 \%$ \\
\hline Коефіцієнт Шарпа & 0,34 & 0,79 & 0,88 & 0,85 \\
\hline Показник дохідність/ризик & 0,77 & 1,22 & 1,14 & 1,43 \\
\hline Мінімальні інвестиції & 3000 & 6000 & 9000 & 12000 \\
\hline Найдовший період відновлення* & 5 р. 8 міс. & 3 р. 1 міс. & 2 р. 3 міс. & 1 р. 7 міс. \\
\hline
\end{tabular}

*мається на увазі проміжок часу між попереднім піковим значенням та відновленням до цього значення після суттєвого падіння вартості портореля.

Джерело: складено автором на основі [8]

портореля $є$ найнижчий поріг входу, що робить його найбільш доступним серед інших портфелів для інвесторів. Складаючись з одного активу, цей портоель не потребує ребалансування, тобто вартість сплачених комісій за період володіння $€$ найменшою серед інших порторелів. Головним недоліком $€$ дуже висока просадка розміром 50,89\%, яка відбулася після кризи 2008 року, після чого докризова вартість портфеля відновилася лише у березні 2012 року. Тому цей порторель $€$ найменш прийнятним для інвесторів, не схильних до ризику.

2. Помірний інвестиційний порторель (ПОМ). Цей портфель, складаючись лише 3 двох активів, продемонстрував найвищу дохідність серед усіх інших змодельованих портоелів. Порівняно 3 пасивним порторелем акцій він також $є$ значно менш ризиковим, оскільки максимальна просадка $€$ майже удвічі меншою, як і волатильність. Однак максимальна просадка може бути неприйнятною для інвесторів із ризик-консервативним профрілем вподобань, поріг входу є вищим, а з необхідністю ребалансування зростає і вартість сплачених комісій за період володіння.

3. Консервативний інвестиційний порторель (КОН). Такий порторель $€$ найбільш прийнятним для консервативних інвесторів, адже його дохідність навіть вища за дохідність пасивного портфеля акцій, проте він $€$ найменш ризиковим, про що свідчать найкращі показники волатильності, максимальної просадки, коефріцієнтів бета та Шарпа. Водноча цей порторель $€$ менш доступним для інвесторів через вищий поріг входу.

4. Ризик-консервативний інвестиційний портфель (Р-КОН). У склад цього портфеля включено золото, яке історично є захисним та антиінфрляційним активом. Дохідністю портфрель поступається лише помірному портфрелю, а ризиковістю - консервативному. Він має найкращий показник дохідності на прийнятий ризик, а також найбільш швидкоплинну корекцію та найнижчий коефріцієнт бети.
Маючи найбільшу кількість активів у складі, він також має найвищий поріг входу.

Оскільки кожний портфель має свої переваги та недоліки, для визначення найбільш оптимального підходу проведемо комплексний аналіз портфрелів, оцінивши кожний показник окремо, де найкращий показник серед інших портфелів отримає найвищий бал, після чого знайдемо суму таких балів. Цей підхід $€$ доцільним, коли показники порівнювальних об'єктів є рівнозначно важливими для оцінки. У нашому разі показники є рівнозначно важливими, адже визначений оптимальний підхід має задовольнити інтереси інвестора з будь-яким профрілем інвестиційних уподобань.

Отже, на основі комплексного аналізу 3 табл. 3 можемо дійти висновку, що найбільш ефеективним порторелем $€$ ризик-консервативний інвестиційний портфель, а найбільш оптимальний підхід - найвища диверсифрікація портореля. Така диверсифрікація $€$ ефективною насамперед через те, що активи у складі портореля мають низьку кореляцію з ринком акцій США та помірно-низьку кореляцію між собою, про що свідчать дані з табл. 4.

Під час моделювання інвестиційних порторелів було зазначено припущення, що ребалансування портоелів відбувалося на щорічній основі протягом 20 років. Проте чи впливає частота ребалансування на ефективність показників портореля? Якщо так, то наскільки сильно та яка частота $€$ найбільш ефективною? щоб знайти відповідь на ці питання, змоделюємо ризик-консервативний інвестиційний порторель за різною частотою ребалансування.

Як ми можемо бачити 3 даних таблиці 5, найбільш суттєва різниця виникає між відсутністю та наявністю ребалансування, при цьому частота ребалансування лише незначною мірою впливає на показники портореля. Тому найесрективнішою частотою ребалансування залишається щорічна, що принесла найбільшу дохідність наприкінці періоду інвестування, а також мала найменшу 
Таблиця 3

Комплексний аналіз показників портфеля

\begin{tabular}{|l|c|c|c|c|}
\hline \multicolumn{1}{|c|}{ Показник портфелю } & ПАС & ПОМ & KOH & P-KOH \\
\hline Баланс наприкінці періоду інвестування & 1 & 4 & 2 & 3 \\
\hline Середньорічний приріст капіталу & 1 & 4 & 2 & 3 \\
\hline Середньорічна волатильність & 1 & 2 & 4 & 3 \\
\hline Коефіцієнт Бета & 1 & 2 & 3 & 4 \\
\hline Максимальна просадка & 1 & 2 & 4 & 3 \\
\hline Коефіцієнт Шарпа & 1 & 2 & 4 & 3 \\
\hline Показник дохідність/ризик & 1 & 3 & 2 & 4 \\
\hline Мінімальні інвестиції & 4 & 3 & 2 & 1 \\
\hline Найдовший період відновлення夫 & 2 & 2 & 3 & 4 \\
\hline Загальна оцінка & $\mathbf{1 3}$ & $\mathbf{2 4}$ & $\mathbf{2 6}$ & $\mathbf{2 8}$ \\
\hline
\end{tabular}

Джерело: складено автором

Таблиця 4

Кореляційна матриця активів ризик-консервативного інвестиційного портфеля

\begin{tabular}{|l|c|c|c|c|}
\hline & Ринок акцій США & Довг. облігації & Коротк. облігації & Золото \\
\hline Ринок акцій США & 1 & $-0,31$ & $-0,35$ & 0,05 \\
\hline Довг. облігації & $-0,31$ & 1 & 0,63 & 0,22 \\
\hline Коротк. облігації & $-0,35$ & 0,63 & 1 & 0,27 \\
\hline Золото & 0,05 & 0,22 & 0,27 & 1 \\
\hline
\end{tabular}

Джерело: складено автором на основі [8]

Таблиця 5

Показники ризик-консервативного інвестиційного портфеля за різною частотою ребалансування активів у складі портфеля

\begin{tabular}{|l|c|c|c|c|c|}
\hline \multirow{2}{*}{\multicolumn{1}{|c|}{ Показник }} & \multicolumn{5}{|c|}{ Частота ребалансування } \\
\cline { 2 - 6 } & Без ребалансування & Щороку & що-півроку & щоквартально & щомісячно \\
\hline $\begin{array}{l}\text { Баланс наприкінці періоду } \\
\text { інвестування }\end{array}$ & $38607 \$$ & $40735 \$$ & $39980 \$$ & $40681 \$$ & $40172 \$$ \\
\hline $\begin{array}{l}\text { Середньорічний приріст } \\
\text { капіталу }\end{array}$ & $6,84 \%$ & $7,12 \%$ & $7,02 \%$ & $7,11 \%$ & $7,05 \%$ \\
\hline $\begin{array}{l}\text { Середньорічна } \\
\text { волатильність }\end{array}$ & $7,96 \%$ & $6,38 \%$ & $6,34 \%$ & $6,37 \%$ & $6,38 \%$ \\
\hline Коесріцієнт Бета & 0,12 & 0,18 & 0,19 & 0,19 & 0,20 \\
\hline Максимальна просадка & $-15,79 \%$ & $-13,38 \%$ & $-13,57 \%$ & $-13,98 \%$ & $-13,57 \%$ \\
\hline Коесріцієнт Шарпа & 0,67 & 0,85 & 0,84 & 0,85 & 0,84 \\
\hline Показник дохідність/ризик & 1,30 & 1,43 & 1,44 & 1,40 & 1,37 \\
\hline
\end{tabular}

Джерело: складено автором на основі [8]

суму сплачених комісій через найменшу кількість операцій з активами у порторелі.

Висновки 3 проведеного дослідження. Стратегія пасивного управління інвестиційним порторелем передбачає можливість отримання прибутку інвесторами без спеціалізованих знань в інвестиційній індустрії та може слугувати інструментом накопичення та помноження капіталу інвестора, забезпечити фрінансову незалежність як на довгостроковому, так і на середньостроковому горизонті.

Однак ця стратегія не виключає можливої оптимізації з метою покращення показників портфреля, таких як кінцева дохідність чи максимальний ризик. Зазначений у статті стратегічний підхід дав змогу створити порторель, що є ефрективнішим за класичний пасивний порторель, що слідує за ринком акцій, при цьому не порушуючи засад пасивної стратегії управління інвестиційним портфрелем. Результати дослідження можуть бути застосовані на практиці як науково обґрунтовані порторельними менеджерами та індивідуальними інвесторами.

Сорормована наукова новизна дослідження на тему «Порівняльний аналіз стратегічних підходів щодо алокації активів у пасивному управлінні інвестиційним портфелем»: набуло подальшого розвитку обґрунтування підходів щодо алокації агресивних (на прикладі ринку акцій США) та консервативних (на прикладі держоблігацій США та золота) активів у стратегії пасивного управління інвестиційним портоелем; запропоновано метод 
оцінки найбільш оптимального підходу; визначено вплив ребалансування на показники портореля.

Подальші дослідження можуть бути спрямовані на визначення оптимальних підходів залежно від інших фракторів, таких як ребалансування активів на основі поточного стану економічної кон'юнктури у країні, економічному регіоні або світі.

\section{БІБЛІОГРАФІЧНИЙ СПИСОК:}

1. О.О. Бібко, В.М. Гужва. Мультиагентна система для управління інвестиційними портфелями. Бізнесінформ. 2011. № 5(1). С. 52-54.

2. Малкиел Б. Десять главных правил для начинающего инвестора /пер. с англ. Альпина Бизнес Букс. Москва, 2006. 172 с.

3. Інформація та аналітика за індексним фондом Vanguard Total Stock Mkt Idx Inv (VTSMX). Morningstar Financial Research, Analysis, Data and News. URL: https://www.morningstar.com/funds/xnas/vtsmx/quote (дата звернення: 10.06.2020).

4. Інформація та аналітика за індексним фондом Vanguard Long-Term Treasury Inv (VUSTX). Morningstar Financial Research, Analysis, Data and News. URL: https://www.morningstar.com/funds/xnas/ vustx/quote (дата звернення: 10.06.2020).

5. Інформація та аналітика за індексним фондом Vanguard Short-Term Treasury Inv (VFISX). Morningstar Financial Research, Analysis, Data and News. URL: https://www.morningstar.com/funds/xnas/vfisx/quote (дата звернення: 10.06.2020).

6. Інформація та аналітика за індексним фондом SPDR® Gold Shares (GLD). Morningstar Financial Research, Analysis, Data and News. URL: https://www.morningstar.com/etfs/arcx/gld/quote (дата звернення: 10.06.2020).

7. Шарп У., Александер Г., Бэйли Дж. Инвестиции / пер. с англ. Инфра-М. Москва, 1997. 1027 с.

8. Аналітичний ресурс для моделювання та оптимізації портфелю цінних паперів. Portfolio Visualiser. URL: https://www.portfoliovisualizer.com (дата звернення 12.06.2020)

\section{REFERENCES:}

1. O.O. Bibko, V.M. Huzhva (2011) Multyahentna systema dlia upravlinnia investytsiinymy portfeliamy [Multi-agent system for investment portfolio management]. Biznesinform, vol. 5, no. 1, pp. 52-54.

2. Malkiel B. (2006) Desyat' glavnykh pravil dlya nachinayushchego investora [Ten main rules for a novice investor]. Moskow: Al'pina Biznes Buks. (in Russian)

3. Informatsiia ta analityka za indeksnym fondom Vanguard Total Stock Mkt Idx Inv (VTSMX) [Information and analytics on the index fund Vanguard Total Stock Mkt Idx Inv (VTSMX)]. Morningstar Financial Research, Analysis, Data and News. Available at: https://www.morningstar.com/funds/xnas/vtsmx/quote (accessed 10 June 2020).

4. Informatsiia ta analityka za indeksnym fondom Vanguard Long-Term Treasury Inv (VUSTX) [Information and analytics on the index fund Vanguard LongTerm Treasury Inv (VUSTX)] Morningstar Financial Research, Analysis, Data and News. Available at: https://www.morningstar.com/funds/xnas/vustx/quote (accessed 10 June 2020).

5. Informatsiia ta analityka za indeksnym fondom Vanguard Short-Term Treasury Inv (VFISX) [Information and analytics on the index fund Vanguard ShortTerm Treasury Inv (VFISX)] Morningstar Financial Research, Analysis, Data and News. Available at: https://www.morningstar.com/funds/xnas/vfisx/quote (accessed 10 June 2020).

6. Informatsiia ta analityka za indeksnym fondom SPDR ${ }^{\circledR}$ Gold Shares (GLD) [Information and analytics on the index fund SPDR ${ }^{\circ}$ Gold Shares (GLD)] Morningstar Financial Research, Analysis, Data and News. Available at: https://www.morningstar.com/etfs/arcx/gld/ quote (accessed 10 June 2020).

7. Sharp U., Aleksander G., Beyli Dzh. (1997) Investitsii [Investment]. Moskow: Infra-M. (in Russian)

8. Analitychnyi resurs dlia modeliuvannia ta optymizatsii portfeliu tsinnykh paperiv [Analytical resource for modeling and optimization of the securities portfolio] Portfolio Visualiser. Available at: https://www.portfoliovisualizer.com (accessed 12 June 2020). 